\title{
大地震時の火災延焼シミュレーション・システ 厶を用いた地域防災力向上支援研究
}

\author{
二神 透 $1 \cdot$ 大本 翔平 $2 \cdot$ 濱本 憲一郎 3 \\ 1正会員＼cjkstart愛媛大学准教授＼cjkstart総合情報メディアセンター（†790-8577松山市文京町3番地） \\ E-mail:futagami.toru.mu@ehime-u.ac.jp \\ 2学生員 愛媛大学大学院 理工学研究科生産環境工学専攻（†790-8577 松山市文京町3番地） \\ E-mail:omoto.shohei.07@cee.ehime-u.ac.jp \\ 3学生員 愛媛大学大学院 理工学研究科生産環境工学専攻（干790-8577 松山市文京町3番地）
}

E-mail:hamamoto.kenichirou.06@cee.ehime-u.ac.jp

\begin{abstract}
四国においては，来るべき南海・東南海地震に備える必要がある. 特に市街地では, 木造密集市街地で の地震火災延焼リスクが想定される。さらに，気象条件である風速が大きい場合，同時多発による延焼リ スクは劦威となり，多くの人的生命の喪失に繋がると想定される.

本研究は, 香川県唯一の密集市街地である, 丸亀市御供所町1)を対象とした地域防災力の向上に向けた, リスク・コミュニケーションについて述べる。具体的には，地域のキーパーソンと著者らが，大地震時の 火災延焼シミュレーション・システムを援用しながら，自主防災組織の結成，防災訓練の実施といった， 地域のPDCAサイクルによる地域防災力の向上に向けた実践研究を報告する。その過程で, 著者らが開発 している大地震時の火災延焼シミュレーション・システムが，支援システムとして，地域コミュニティの BCPに果たしている役割と課題について述べる.
\end{abstract}

Key Words :community disaster prevention, spreading of fire, BCP of community, big earthquake

\section{1. はじめに}

2011年3月11日に発生した東日本大震災は，東北地方 太平洋側へ未曽有の被害をもたらした。この地震では大 津波が発生し，死者・行方不明者合わせて 2 万人を超す 甚大な被害となった。津波以外にも液状化現象や地盤沈 下，地震火災，地滑りなどによる被害があったが，死 者・行方不明者の約9割が津波によるものであったため, 地震火災の被害はほとんど取り上げられていなかった。

四国においても，今後30年以内で $60 \%$ の確率で発生す ると想定されている南海・東南海地震に対して, 命を守 るための対策を講じる必要がある2). 今回の震災では, 津波被害が特徴的であったが，南海・東南地震では、地 域特性ごとに災害リスクは異なってくるであろう。その ために，災害時に人的被害を最小限に抑えるためには， 地域ごとに災害リスクを想定し，想定外を想定内に収め ることが大事である，そのうえで重要となるのが，災害 のリスクを提示し，かつ，都市計画的なハード対策の効 果や，避難計画などのソフト対策に有効な支援システム の存在であると考えている. 支援システムを活用するこ
とで，専門家が住民（自主防災組織）と連携しながら， 地域の防災力を高めていけるのではと考えている，その 意味では，自主防災組織の防災意識の底上，すなわち， PDCA型の活動が鍵になるであろう。しかし，平成23年4 月現在，松山における自主防災組織の結成率（結成率= 自主防災組織加入世帯数／松山市世帯数） ${ }^{3)}$ は， 99.9\% と高い水準を達成しているが，組織を結成しているだけ で機能していないものも多い.さらに，県内200市町村 を眺めれば，地域によっては，そもそも自主防災組織が 結成されていないところも多々ある．特に，市街地中心 部の，マンション等の集合住宅は，自治会と独立な管理 体制を採るところが多いのも原因の一つである。一方, 地域の災害危険性を認識できないが故, 自主防災組織の 結成が遅れている地域も多い.

本稿では，建物の位置と属性などの，地域固有の都市 構造や気象条件といった外生変数を要因として与えるこ とで，地震火災時の延焼状態が出力されるという支援シ ステムの観点から, 丸亀市城北地区のキーパーソンから 依頼を受け，自主防災組織の結成と避難訓練に至るまで のプロセスを，時系列で整理し報告する，さらに，実験 
計画法を用いて支援システムの要因分析を行い，都市計 画的な整備効果の評価と，対象地域以外でシステムを用 いる場合の要因の取得精度について述べるとともに，今 後の更なる地域防災力の向上にむけた支援システムの活 用について述べる.

\section{2. 丸亀市城北地区を対象とした実践研究}

\section{（1）丸亀市での研究実践の背景}

丸亀市を対象に，大地震時の火災延焼シミュレーシ ヨンを用いて，自治会役員らと自主防災組織の結成に 向けた活動を行うようになったのは，著者のTVメディ アへの出演がきっかけとなっている．著者の研究の一
つである，防火樹木による地震火災リスクの低減効果 の放映をTVで見た丸亀市・城北コミュニティの自治会 役員が，著者に講演依頼を行った。その目的は，丸亀 市城北地区には，香川県で唯一の重点密集市街地が存 在しているが，住民の危機意識が低く，自主防災組織 が結成されていないため、講演が起爆剤になればと考 えたからである．表-1に，2009年1月のTV出演の後，同 年5月16日から始まった，城北コミュニティでの活動を 示す4). 講演会では, 阪神淡路大震災の火災状況と対策 や，松山市での取り組みについての情報提供を行った。 しかし，講演後に住民の方から「この地域についての 情報が聞けると思っていた」との意見をいただいた。 これを踏まえ，本格的に丸亀市城北地区を対象として，

表-1 丸亀市城北コミュニティにおける地域防災力支援内容

\begin{tabular}{|c|c|c|}
\hline 年月日 & 活 動 項 目 & 内 \\
\hline 2009.1.10. & テレビ出演 & $\begin{array}{l}\text { 防火樹木の効果についての番組(某全国ネット) } \\
\rightarrow \text { 後日, 御供所自治会長から講演依頼 } \\
\end{array}$ \\
\hline 2009.5.16. & 講演会の実施 & 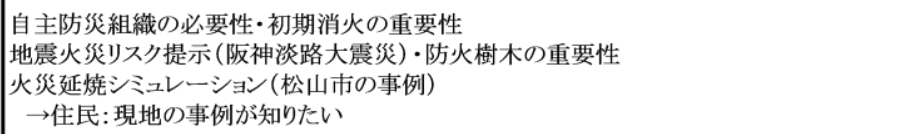 \\
\hline \multirow{2}{*}{ 2009.8.10. } & 現地調查(1回目) & デジタルカメラと電子地図を用いての調査 \\
\hline & ヒアリング(丸亀市役所) & 都市計画に関する情報のヒアリング \\
\hline \multirow{2}{*}{ 2009.11.1. } & 現地調查(2回目) & ビデオカメラとGPSデバイスを用いての調查 \\
\hline & ヒアリング(防災会長) & 住民が行っている防災対策についてのヒアリング \\
\hline \multirow{2}{*}{ 2009.11.29. } & 現地調查(3回目) & デジタルカメラとGPSデバイスを用いての調査 \\
\hline & ヒアリング(防災会長) & 住民が行っている防災対策についてのヒアリング \\
\hline 2009.12.17. & ワークショップ(行政) & \begin{tabular}{|l} 
火災延焼シミュレーションを用いた活動 \\
危機管理課・消防管理課の方が参加した
\end{tabular} \\
\hline 2010.2 .21 & データの確認 & $\begin{array}{l}\text { 城北地区自治会役員から建物データの誤りの指摘 } \\
\rightarrow \text { 再調查を実施することに }\end{array}$ \\
\hline 2010.3.14-15. & 再調査 & $\begin{array}{l}\text { 城北地区自治会役員自ら建物データを採取 } \\
\text { ，地域住民とデータを採取し, 納得のいく基礎データを採取すること } \\
\text { 都市構造データを即時修正可能なシミュレーションにすることが重要 }\end{array}$ \\
\hline \multirow[t]{2}{*}{ 2010.4.24. } & $\begin{array}{l}\text { 火災延焼シミュレーション } \\
\text { の拡張化 }\end{array}$ & 再調査後のデータを城北地区自治会役員に見てもらい, 不備のある個所を即時修正 \\
\hline & シナリオ設定 & シミュレーションシナリオを設定した \\
\hline \multirow[t]{2}{*}{ 2010.7.25. } & 講演会の実施 & $\begin{array}{l}\text { 自主防災組織の必要性·初期消火の重要性 } \\
\text { 火災延焼シミュレーション(御供所地区の事例) } \\
\text { 風速の違いによるリスク } \\
\text { 都市計画的対策によるリスクの低減効果 }\end{array}$ \\
\hline & アンケートの実施 & 防災に関する意識調查・シミュレーションに対する意見の自由記述 \\
\hline \multirow[b]{2}{*}{2010.10 .2} & アンケート結果の説明 & レイアウトやグラフの形式が悪からたので, 後日修正版を配布 \\
\hline & $\begin{array}{l}\text { シミュレーション結果の } \\
\text { 比較動画の紹介 }\end{array}$ & $\begin{array}{l}\text { 防火対策の有無で効果がどう変わってくるかを比較したもの } \\
\text { 城北地区自治会役員より修正のお願い(焼失面積・経過時間の字が小さい) } \\
\text { 修正後, 8パターン比較動画を収録したDVDを配布 }\end{array}$ \\
\hline 2010.10.31. & 会議 (避難訓練) & $\begin{array}{l}\text { 避難訓練の重要性を説く } \\
\text { 避難訓練の際にGPSを付けてもらうよう依頼 }\end{array}$ \\
\hline 2010.11.27. & GPSの使い方の説明 & GPSを配布する自治会を決定した(8地区) \\
\hline 2010.12.5. & $\begin{array}{l}\text { 避難訓練・防災訓練の } \\
\text { 実施 (城北地区) }\end{array}$ & $\begin{array}{l}\text { 参加人数: } 345 \text { 人 } \\
\text { 避難経路のGPSデータが取れていたのは4地区だった } \\
\text { 【防災訓練内容】 } \\
\text { 担架の作り方, 土のうの作り方, 発電機の使い方, 水消火器訓練, 油消火器訓練, バケツ } \\
\text { リレー訓練, 救命ボートの準備, 簡易トイレ設営, 非常食体験 }\end{array}$ \\
\hline 2011.1.30. & コミュニケーションの振り返り & 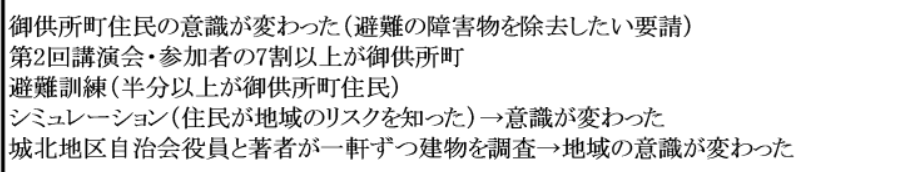 \\
\hline
\end{tabular}


支援システムを活用した地域防災力向上化のための研 究を行うこととした.

\section{（2）対象地域都市構造データの採取}

著者らは，表-1に示寸ように，講演会終了後，自治体 役員や，行政へのヒアリングを行うとともに，密集市街 地の都市構造データの採取を行った。対象地域で採取し た最終的なマップを図-1に示す。茶色（濃淡2種類）が, 純木造，防火木造の建物である。一方，グレーの建物

（○印）は，耐火建物である．図-1に示すように，地域 の道路は，狭小であるため，地元の自治会長の誘導の下， デジタルカメラや電子地図，GPSデバイスなどを用いて， 3度に分けた現地調査を行った。

調査データを基に，大学研究室にて城北地区御供所町 周辺を再現した都市構造マップを作成した．作成したマ ップを城北地区自治会役員と御供所自治会長に確認して いただいたところ，多くの建物の位置や属性の再現性に 誤りがあるといった指摘をいただいた．御供所自治会長 より，このままのデータでは，地域住民から不平・批判 が出るかも知れないとの指摘を受け，会長自ら，再調査 をしようと申し出てくれた，それを受けて，今後の指摘 も想定し，支援システムの改良を行い，入力した建物の 位置や属性を任意に変更できるよう改良を行った。この 機能を付与することにより，住民の指摘をその場でシス テムに反映することが可能となる．御供所自治会長，城 北地区自治会役員らに，最終確認をいただいたマップが， 図-1である。

その後，丸亀市城北地区において，第二回目の講演会 を行った。この講演会では，採取したデータを用いて， 前回の講演会では触れていなかった城北地区における災 害危険性についての紹介を行った．建物が密集している ために，短時間で多数の建物が延焼してしまう恐れがあ ることを説明し，支援システムを使用することで，出火 点の数や気象条件・対策の有無の違いにより延焼面積が どのように変わってくるのかについて提示した．なお， この講演会の参加者のうち，7割が御供所町の住民であ

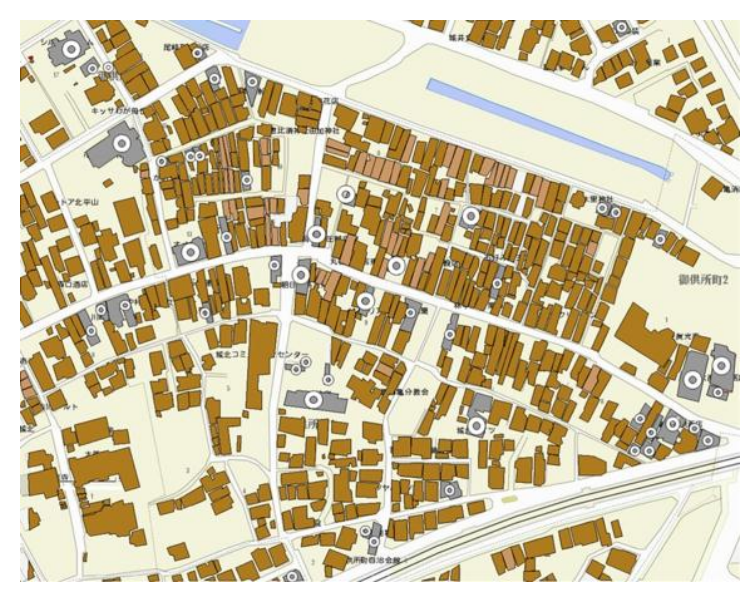

図-1 御供所町周辺の都市構造マップ
った.これは, 御供所自治会長が御供所町自治会所属の 住民寸べての家にチラシを配布したためである.

講演会後に, 参加者に対してアンケートを実施した. それらの結果の一部を，図-2に示寸、はじめに，支援シ ステムを見て，少しでも火災延焼の危険性を感じた人は 全体の $92 \% お り ，$ 地域の危険性の認識を植え付けること ができたといえる．次に，防火樹木の効果についての質 問では，効果を知らない人が $31 \%$ いことが分かった. 防火樹木は火災延焼抑止には効果的なため，住民の方に 認知してもらえるように説明していくことが重要だと考 える．自主防災組織の有用性についての質問では，住民
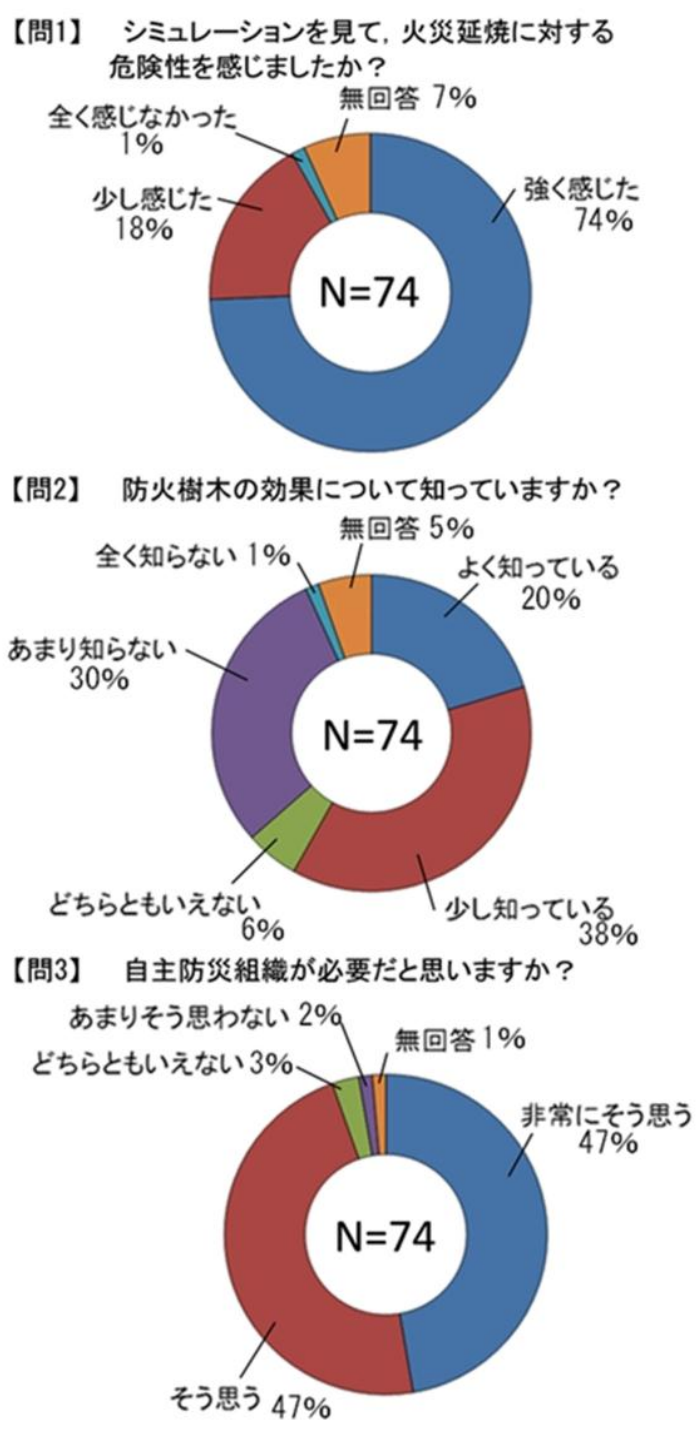

【問4】要援護者の支援が必要だと思いますか?

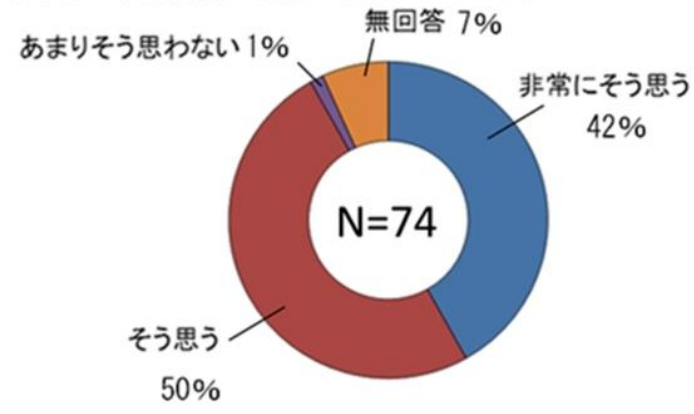

図-2＼cjkstart講演後のアンケート結果 
の $94 \%$ のが自主防災組織を必要と感じていることがわ かった。講演会実施時には城北地区に自主防災組織は結 成されていなかったが，この講演会後に，丸亀市城北地 区に自主防災組織が結成された，これについては後述す る. 最後に，要援護者支援の有用性についての質問では, $92 \%$ ○が要援護者の支援の必要性を感じていることが 分かった. 城北地区では高齢化が進んでおり, 要援護者 支援についてどう取り組んでいくかが，今後，住民間で の大きな課題となってくるだろう.

このように，第二回目の講演会では，支援システムに より，条件ごとの火災の危険性の提示を行い，アンケー トから住民の生の声を取得した，その後，支援システム による危険性の提示を理解しやすく編集してまとめた DVDの配布とアンケート結果の報告を行った。その際 に御供所自治会長より, わかりにくい個所があるといっ た指摘を受けたため, 修正を加えたものを後日再提供し た.

第二回目の講演会から1ヶ月後には自主防災組織が結 成され，その4ケ月後には第一回自主防災訓練が実施さ れた．第一回目の訓練ということで，自治会役員に限定 して参加者を募っていたが，当日は予定人数よりも 100 人以上多い 345 人が参加した．防災訓練では，応急担架 の作り方や消火器の使い方等, 全 9 項目の訓練が実施さ れ, 参加者は意欲的に訓練に臨んでいた.

その後, 著者は関係者と, これまでの活動を振り返る ためのワークショップを行った. その際, 度重なる現地 調查や講演会で地元の危険性を紹介したことで, 住民の 意識が変わり始め, 地震火災リスクを認識し防災意識が 高まったことが，自主防災組織の結成につながったので はないかと，城北地区自治会役員らより意見を得た．住 民の意識の変化は, 防災訓練の参加を断る人がいなかっ たこと, 役員ではないが参加したいという声があったこ と, 避難路の障害物を除去してほしいという要請があっ たことなどから感じ取ることができる，また，このワー クショップを通じて今後の課題もいくつか挙がった. 今 回の活動で, 重点密集市街地を有する御供所町について は，防災意識が向上し，地域全体で自主防災組織が結成 されるという波及効果が見られたが，城北コミュニティ 内には同様の密集市街地が存在しているため, 今後は対 象地域を変更して同じように見せていただきたい，との 要請を城北地区自治会役員より受けた。 また，専門家の 負担軽減の意味においても，専門家以外の人々が支援シ ステムを活用できるよう，人材育成が必要であると考え ている，これについては，若者等の新たな住民ネットワ 一クの形成が今後の課題であるという意見を城北地区自 治会役員より頂いた.

\section{3. 今後の対策に向けた支援システム分析}

\section{(1) 都市計画的対策に向けた分析}

本稿の冒頭て触れたように，著者らが開発している大 地震時の火災延焼シミュレーション・システムは, 浜田 の延焼速度式に従い, シミュレーション実施により地震 火災時の延焼状態が出力される5). また, 過去には本シ ステムよりも荒いメッシュでのシミュレーションにより， 火災の再現性が確認されているす . 都市構造や気象条件 といった要因が, 出力結果にどの程度の影響を与えてい るのかについて把握することは, 今後, 採取するデータ の精度や，この地域の都市計画に影響を与える要因を把 握する意味においても重要な視点となる. そこで, 実験 計画法を利用した要因の分析を試みる.

はじめに, 延焼面積に影響を与える要因として, 都市 構造マップ $(\mathrm{M})$ ，風速（WV），風向（WD），建ぺ い率（BL）の4つの要因を取り上げ，表-2に示すように， 要因ごとにそれぞれ3つの水準を設ける。なお，気象条 件はヒアリングから得た情報より設定した．また，都市 構造マップの水準は, 今後の都市計画的な対策を睨んで 設定している. 寸なわち，都市計画道路を図-3のように 想定したマップと，防火樹木の設置を図-4のように想定 したマップである. なお，現状については，すでに示し た図ー1のマップを使用する.

今回は，シミュレーション実行の際に対象範囲外まで 延焼が進むと延焼面積が正しく反映されないことを考慮 し, 延焼開始から120分時点での延焼面積を特性值とす る. また, 出火点による考慮を行うため, 9通りの実験

表-2 要因と水準

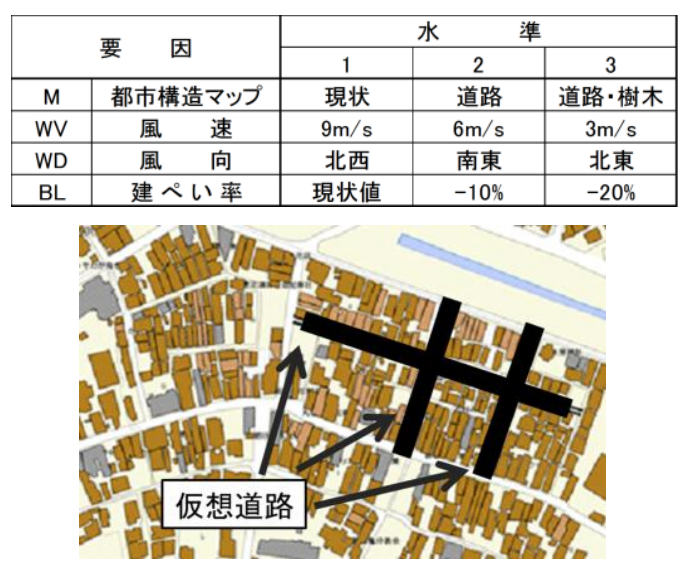

図-3 道路設置箇所

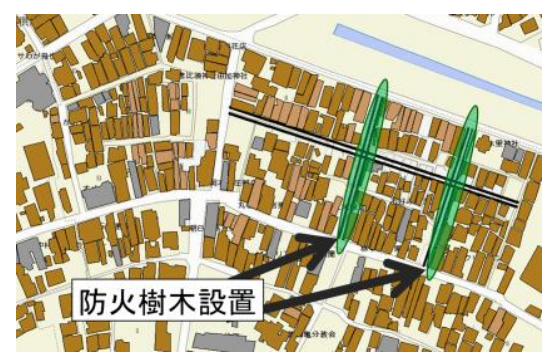

図-4 防火樹木設置箇所 
での出火点は同じ箇所とし，得られた9通りの特性值を1 組とする．その後，出火点を変えて同様に9通りの実験 を行う。2組の実験結果を用いて分析を行っていく．な お，特性值をすべて得るためには $3^{4}$ 通り，つまり81通り の組み合わせで実験をする必要があるが，今回は実験計 画法における直交表に従い，9通りの実験を行うことで 特性值を得るよう，情報の効率化を図った7).

\section{(3) 要因分析の実施}

表-3に示す結果を見てみると，風速の寄与率が $77.8 \%$ と，非常に大きな值を占めた，それに続いたのは建ぺい 率で，寄与率は $11.5 \%$ であった。一方，寄与率が大きく なると推測していた都市構造マップについては，2.3\%で あり，非常に小さい值を取る結果となった。ここでは， 風速の寄与率が大きくなるという結果を得たが，これは 風速の水準が大きいために防火樹木が効果を発揮しなか ったためであると考えられる，本来，防火樹木は火災延 焼の抑止に効果的であるが，大きい風速のために風速の 寄与率が高くなり，都市構造マップの寄与率が低い值に なったと推測される，そこで，風速の水準を変更して， 同様に実験計画法を用いた要因分析を再度行うことにし た.

再分析では，風速の水準を9・6・3( $\mathrm{m} / \mathrm{s})$ から5・4・ $3(\mathrm{~m} / \mathrm{s})$ 一と変更した．他の要因については水準の変更は 行わないものとして，再分析を行う.

各要因を組み合わせた9通りのシミュレーションとそ の際の特性值を表-4に示す．延焼面積の最大值と最小值

表-3 寄与率一覧

\begin{tabular}{|c|c|c|}
\hline 要 因 & $\begin{array}{c}\text { 寄与率 } \\
(\%)\end{array}$ & F値 \\
\hline 都市構造マップ & 2.3 & 9.6 \\
\hline 風＼cjkstart速 & 77.8 & 289.7 \\
\hline 風向 & 6.1 & 23.7 \\
\hline 建ぺい率 & 11.5 & 43.5 \\
\hline 誤 差 項 & 2.3 & \\
\hline 合 計 & 100 & \\
\hline
\end{tabular}

表-4 特性值一覧（再分析）

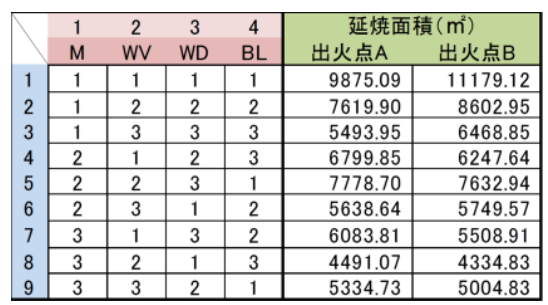

表 -5 寄与率一覧（再分析）

\begin{tabular}{|c|c|c|}
\hline 要 因 & $\begin{array}{c}\text { 寄与率 } \\
(\%)\end{array}$ & F値 \\
\hline 都市構造マップ & 48.8 & 58.4 \\
\hline 風速 & 20.2 & 24.8 \\
\hline 建ぺい率 & 23.8 & 29.1 \\
\hline 誤 差 項 & 7.2 & \\
\hline 合 計 & 100 & \\
\hline
\end{tabular}

には差が出ていることから，要因の違いによる影響があ るといえる. 得られた数值を用いて分散分析を行ったと ころ，表-5に示すように寄与率を得た．なお，各要因の 寄与率については，F検定で $1 \%$ 有意である。風向の寄与 率は誤差項にプールした。

結果を見ると，都市構造マップの寄与率が $48.8 \%$ と大 きい值を得た。それに続いて建ぺい率と風速の寄与率が それぞれ $23.8 \% ， 20.2 \%$ という值となった。再分析では風 速の水準を変更したため，風速の寄与率が下がり，都市 構造マップの寄与率が上昇すると推測していたが，その 通りの結果が得られた。

また，要因の効果図を描くと，図-5のようになった。 都市構造マップの効果図を見ると，現状のマップ（M1） $\rightarrow$ 道路設置のマップ（M2）－道路設置十防火樹木配置 のマップ（M3）の順で，延焼面積が小さくなっている. M2 とM3で值が違う点から，防火樹木設置による火災延 焼抑止効果があることがわかる．防火樹木の効果を無視 するほどの強い風でなかったために，このような形状の 効果困になったと推測する.

風速の効果図を見ると，水準変更前と同様に，風速が 小さくなるにつれて延焼面積が小さくなるということが わかる。グラフの形状は上に凸なグラフであることから, 風速が小さくなると延焼面積は小さくなる。しかしその 影響は徐々に大きくなるといえる.

建ぺい率の効果困については，数值が小さくなるにつ れて延焼面積が小さくなっている.グラフの形状は下に 凸であることから，数值が小さくなるにつれて延焼面積
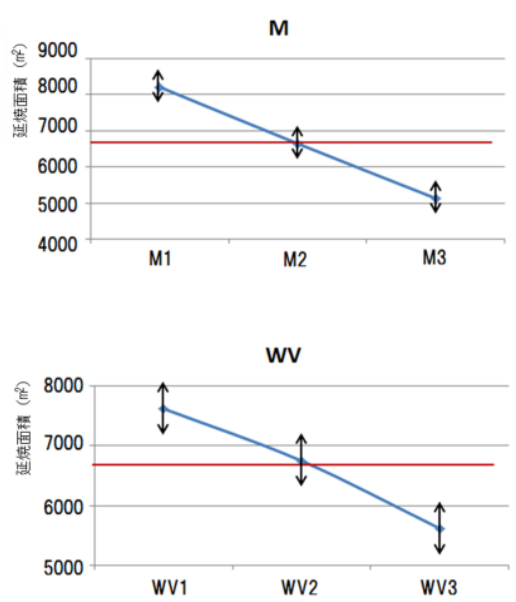

BL

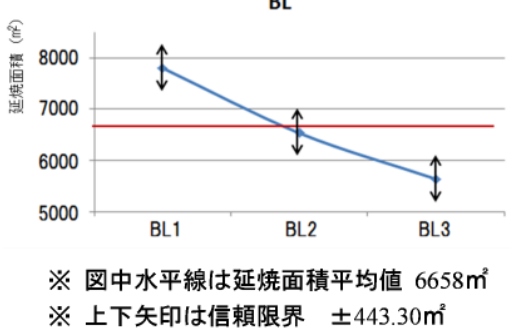

図-5＼cjkstart要因の効果図（再分析） 
の減少効果が小さくなることが分かる.

風速の值の変更前後での 2 つ分析を比較してみると, 影響度を示す寄与率に大きく違いが出た。風速が $6 \mathrm{~m} / \mathrm{s}$ 以上となると，風速の寄与率が非常に高くなり，都市構 造マップや建ぺ率の寄与率は極端に低くなる．風速が 大きくなると，都市計画的な対策による火災延焼抑止効 果は現れず，風速の大きさに比例して延焼面積が大きく なるといえる。一方，風速が $5 \mathrm{~m} / \mathrm{s}$ 以下の場合には，都 市構造マップや建ぺい率の寄与率が高くなっており，都 市計画的な対策を行うことで，火災延焼面積を低減させ る効果があることが分かった。

\section{4. まとめ}

本稿では，丸亀市城北地区を対象に行ってきた活動内 容を紹介した．著者らと城北コミュニティの自治会役員 城北地区自治会役員・御供所自治会長が活動を行ってい く中で，住民の意識が変動する様子が見られた．講演会 後1ケ月で自主防災組織が結成されたこと，積極的な防 災訓練への参加にも，その影響が表れている。今回は御 供所町周辺を対象としたシミュレーションを提示したた めに，主に御供所町住民の意識が変動し，地域全体の自 主防災組織の結成に搫がった。このようにPDCA型の活 動を行い，自主防災組織の結成という結果にたどり着い たが，結成された組織を継続していくためには，地区全 体の防災意識の向上や，支援システムを使える人材の育 成が必須となる．新たに生まれたこれらの課題に対応す るためには，継続的にPDCA型の活動を実施していくこ とが望ましいと言えよう。城北地区自治会役員からの要 請にあったように，対象地域を変えて地震火災のリスク 提示を行うことは，今後のPDCA型の活動のひとつとし て考えられる.

また，丸亀市城北地区を対象とした火災延焼の要因分

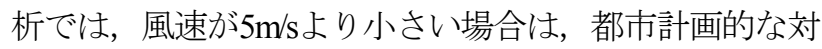
策を行うと延焼面積が少なくなることが分かった。一方，

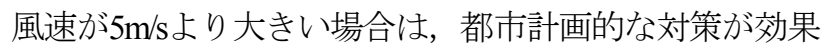

を発揮せず，風速の影響が大きくなることが分かった. このように，城北地区においては，風速が地震火災被害 の程度に影響を与えるうえでのポイントとなる.今後城 北地区において何らかの都市計画的な対策を実施する際 には，風速の影響を考慮する必要があると考える。しか し，今回の分析では適用した要因数は少なく，要因間の 交互作用を見ることができないといった問題がある。今 後, より詳しい分析を行う際には，分析に適用する要因 数を増やし, 要因の組み合わせのパターンを多くするこ とで，要因間の交互作用も考慮した，より信頼できる影 響度の把握ができると考えている.

\section{参考文献}

1) 国土交通省ホームページ「地震時等において大規模 な火災の可能性があり重点的に改善すべき密集市街 地」について

(http://www.mlit.go.jp/kisha/kisha03/07/070711_html)

2) 地震調査研究推進本部ホームページ「海溝型地震の 長期評価の概要」

(http://www.jishin.go.jp/main/choukihyoka/kaikou.htm)

3) 松山市ホームページ「自主防災組織の結成経過状況」 ( http://www.city.matsuyama.ehime.jp/ICSFiles/afieldfile/2011/0 6/20/kesseijyoukyou.pdf)

4) 二神 透, 木俣 昇, 濱本憲一郎 : 密集市街地にお けるリスクコミュニケーションの展開研究，第42回 土木計画学研究・講演集 (CD-ROM) ，4項， 2010.

5) 二神 透，木俣 昇：住民参加のための大震時火災 延焼シミュレーション・システム開発，土木情報利 用技術論文集 17 pp.39〜 46，2008.

6) 木俣 昇：大震時避難計画のためのメッシュ型火災 延焼シミュレーション・システムに関する検証, Journal of the Operations Research Society of Japan 30(1), 59-87, 1987

7) 田口玄一：実験計画法 上下，丸善株式会社，1976.

\title{
IMPROVEMENT SUPPORT RESEARCH OF LOCAL DISASTER PREVENTION POWER USING THE FIRE SPREADING SIMULATION SYSTEM IN CASE OF A BIG EARTHQUAKE
}

\section{Toru FUTAGAMI, Shohei OMOTO and Kenichirou HAMAMOTO}

\begin{abstract}
This research describes the risk communication towards improvement in the local disaster prevention power for Gobusho town in Marugame city which is only a high density city area in Kagawa Pref. Specifically, the key persons and authors of the area report the practice research towards improvement in the local disaster prevention power by the PDCA cycle of the area, such as formation of local voluntary disaster management organizations and implementation of an emergency drill, applying the fire spreading simulation system in case of a big earthquake. The fire spreading simulation system in case of the big earthquake which authors are developing describes the role and subject which have been achieved to BCP of the local community as a support system.
\end{abstract}

